\title{
Exploring a multifunctional geoengineering material for eutrophication remediation: simultaneously control internal nutrient load and tackle hypoxia
}

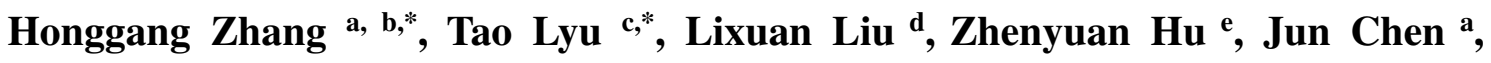
Bensheng Su ${ }^{\mathrm{d}}$, Jianwei $\mathrm{Yu}^{\mathrm{a}}$, and Gang Pan ${ }^{\mathrm{f}}$

${ }^{a}$ State Key Laboratory of Environmental Aquatic Chemistry, Research Center for EcoEnvironmental Sciences, Chinese Academy of Sciences, Beijing 100085, China

${ }^{\mathrm{b}}$ Yangtze River Delta Branch, Research Center for Eco-Environmental Sciences, Chinese Academy of Sciences, Yiwu 322000, China

${ }^{\mathrm{c}}$ Cranfield Water Science Institute, Cranfield University, College Road, Cranfield, MK43 OAL, UK

${ }^{\mathrm{d}}$ High-Tech Research Institute, Beijing University of Chemical Technology, Beijing, 100029, China

${ }^{e}$ Administration Office of the Summer Palace, Beijing 100091, China

${ }^{\mathrm{f}}$ School of Animal, Rural and Environmental Sciences, Nottingham Trent University, Brackenhurst Campus, NG25 0QF, UK

*Corresponding authors: hgzhang@ rcees.ac.cn (H. Zhang); t.lyu@ cranfield.ac.uk (T. Lyu) 


\section{Abstract}

An effective approach for control of internal nutrient loading and sediment hypoxia remains a longstanding challenge to the restoration of aquatic ecosystems. In order to simultaneously tackle these issues, a MultiFunction Geoengineering material (MFG) was developed for sediment remediation through the synergistic functions of physical capping, nutrient adsorption and delivery of $\mathrm{O}_{2}$ nanobubbles. The MFG, derived from natural zeolite, exhibited superior (1.5-4 times higher) adsorption capabilities for both phosphate $\left(\mathrm{PO}_{4}{ }^{3-}-\mathrm{P}\right)$ and ammonium $\left(\mathrm{NH}_{4}{ }^{+}-\mathrm{N}\right)$, than pristine zeolite. The $\mathrm{O}_{2}$ adsorption capacity was also enhanced from 46, observed in the natural zeolite, to $121 \mathrm{mg} \mathrm{O}_{2} / \mathrm{g}$ for the MFG. An in-situ sediment capping experiment in a eutrophic lake demonstrated that the application of MFG dramatically reversed sediment hypoxia (ORP -200 mV) to an aerobic status (ORP $175 \mathrm{mV}$ ) and, furthermore, stimulated sediment microbial activity, particularly nitrifying bacteria. The MFG treatment resulted the sediment changing from a nutrient source to a sink through decreasing the cumulative $\mathrm{PO}_{4}{ }^{3-}-\mathrm{P}$ and $\mathrm{NH}_{4}{ }^{+}-\mathrm{N}$ fluxes from the sediment by $124.6 \%$ and $131.1 \%$, respectively. Moreover, the comprehensive functionalities of the material have been, for the first time, quantified, from which data $\mathrm{O}_{2}$ nanobubble delivery was determined to be the largest contributor, reducing the fluxes of $\mathrm{PO}_{4}{ }^{3-}-\mathrm{P}$ and $\mathrm{NH}_{4}{ }^{+}-\mathrm{N}$ by $57.3 \%$ and $56.1 \%$ of, respectively. Our findings highlight the viability of such multifunctional material for the remediation of internal nutrient loads in lacustrine environments, towards sustainable eutrophication control.

Keywords: Eutrophication; internal loading; lake or reservoir restoration; oxygen nanobubble; sediment anoxia 


\section{Introduction}

Eutrophication of water bodies, both natural and artificial, is spreading globally, causing such serious consequences as Harmful Algal Blooms (HABs) [1] and/or black odorous water [2]. These nuisance phenomena pose serious threats to the aquatic ecosystem, to the environment, and to public health [3]. It is generally agreed that management of the dual nutrients, phosphate $\left(\mathrm{PO}_{4}{ }^{3-}-\mathrm{P}\right)$ and ammonium $\left(\mathrm{NH}_{4}{ }^{+}-\mathrm{N}\right)$, could produce a sustainable, long-term, improvement in lake water quality towards remediation of eutrophication [4]. However, consequent to the control of external nutrient loading from anthropogenic discharges through strict statutory requirements and implementations, internal loadings of $\mathrm{NH}_{4}{ }^{+}-\mathrm{N}$ and $\mathrm{PO}_{4}{ }^{3-}-\mathrm{P}$ from sediments may be expected to prolong eutrophication episode and impose continuous pressure on aquatic ecosystems, perhaps over subsequent decades $[5,6]$. Therefore, measures for reduction of internal nutrient loadings have recently attracted increasing attention.

Various approaches have been developed to reduce nutrient loadings from sediment, including dredging [7], aeration or oxygenation [8], use of chemical flocculants [9] and in situ capping [10]. Among them, capping of contaminated sediment has been suggested to be potentially the most effective method for the control of eutrophication in lakes [11, 12]. Capping treatment in lakes, by the spraying of natural materials, such as sand, clay, gravel and rock, could form a physical barrier on surficial sediments and effectively prevent nutrients from entering into the water. Synthetic materials, such as lanthanummodified bentonite (Phoslock ${ }^{\mathrm{TM}}$ ) and aluminium-modified zeolite (Aqual-P), have been developed to augment the functionality from existing as a purely physical barrier to 
additionally acting as an active $\mathrm{P}$ adsorbent $[13,14]$. Some synthetic materials have also been used to further adsorb both $\mathrm{P}$ and $\mathrm{N}$ released from sediments [15]. However, the application of these synthetic materials may pose long-term side-effects on aquatic ecosystems through the accumulation and re-release of toxic metals [16]. Moreover, such materials mainly focus on improvements in adsorption capacity, while ignoring the fact that the adsorbed and capped $\mathrm{NH}_{4}{ }^{+}-\mathrm{N}$ and $\mathrm{PO}_{4}{ }^{3-}-\mathrm{P}$ may subsequently be re-released into overlying water due to the aging of materials, hydrodynamic interaction, and changes in environmental conditions, such as decreased redox potential [17].

In eutrophic waters, the consequent oxygen depletion by mineralisation of senescent algal blooms induces hypoxia/anoxia at the sediment-water interface (SWI) [18]. This condition in the bottom water can significantly facilitate the mobility of the nutrients from sediment to water column [19]. Upon aging or saturation, the materials mentioned previously may have limited ability to adsorb excess internal nutrients that experience an accelerated release under hypoxic conditions. Reversal of such hypoxia/anoxia at the SWI can facilitate adsorption $\mathrm{PO}_{4}{ }^{3-}-\mathrm{P}$ by metal oxide-hydroxide complexes [20] and by stimulation of microbial-induced nitrification processes, $\mathrm{NH}_{4}{ }^{+}-\mathrm{N}$ release can be further prevented [21]. Therefore, successfully addressing SWI hypoxia/anoxia is crucial towards the sustainable control of the internal nutrient loadings. However, traditional capping treatments may have limited ability in the remediation of sediment hypoxia, as they do not actively oxygenate bottom sediments.

A few SWI oxygenation methods have been deployed in order to raise or maintain levels of benthic dissolved oxygen (DO), and have been based mainly on the direct 
injection of either air (aeration) [25], or oxygen gas (oxygenation) [8] or through artificial mixing [22]. However, the induced massive hydraulic disturbance may affect benthic biota and lead to both re-suspension of anoxic sediment and increases in internal nutrient loadings and oxygen consumption [23]. The consequences of internal $\mathrm{PO}_{4}{ }^{3-}-\mathrm{P}$ release and response of $\mathrm{HABs}$ to the hypolimnetic aeration/oxygenation in lakes and reservoirs have also been reported $[8,24,25]$. Nevertheless, the costs of such methods are relatively high at large scale (mostly, operational cost is around $\$ 2.5-3 \mathrm{k} / \mathrm{ha} / \mathrm{year}$ ) because the pumping system needs to operate continuously throughout the summer season, or even the whole year, in order to maintain the oxygen supply to the SWI [23]. Hence, an urgent need exists to develop novel geoengineering materials to not only simultaneously control the release of previously buried nutrients from the sediment, but also to reverse the hypoxic conditions at the SWI.

Nanobubbles, also known as ultrafine bubbles (bubble size $<1000 \mathrm{~nm}$ ), have attracted increasing attention in the environmental research area due to their outstanding features of longevity, low buoyancy, and high gas transfer efficiency as compared to larger bubbles [26]. Due to thees characteristics, interfacial/surficial oxygen nanobubble technology was first developed in 2018, using natural minerals loaded with oxygen, delivering nano-scale oxygen bubbles into sediment surfaces in an environmentallyfriendly way [27]. This study has demonstrated that the synergy of diffusion of oxygen nanobubbles and retention of oxygen at the SWI could successfully reverse conditions of hypoxia and reduce fluxes of $\mathrm{N}$ and $\mathrm{P}$ from sediment. These effects have been attributed to the characteristic longevity and high gas solubility of nanobubbles. Following this 
concept, further studies have been conducted by different researchers, mainly focused on the evaluation of hypoxia/anoxia conversion [28], control of nutrient turnover [29], and modulation of organics mineralization [30]. However, the contributions of oxygen delivery and capping treatment to the control of internal nutrient loading has not hitherto been quantitatively investigated.

This study aimed to develop a multifunctional geoengineering material (MFG), which could maximise control of internal nutrient loading through physical capping, nutrient adsorption and remediation of hypoxia at the SWI. Natural zeolite, as an effective $\mathrm{NH}_{4}{ }^{+}-\mathrm{N}$ adsorbent, was selected as the skeleton material. This was then modified in order to increase its capabilities for $\mathrm{PO}_{4}{ }^{3-}-\mathrm{P}$ adsorption and oxygen nanobubble delivery. The material was initially characterised for mineral composition and surface properties. The theoretical abilities for nutrients and oxygen adsorption were also determined. Furthermore, an in-situ experiment was conducted in a eutrophic lake in order to evaluate the real-life performance. The contributions of the different functionalities, i.e. oxygen delivery, nutrient adsorption and capping treatment, of the MFG were quantitatively studied. Moreover, compositional changes of microbial communities in the sediment, before and after treatment, were compared to support our hypotheses about the remediation mechanisms.

\section{Materials and methods}

\subsection{Preparation of MultiFunctional Geoengineering material (MFG)}

Natural zeolite, which recognised to have effective $\mathrm{NH}_{4}{ }^{+}-\mathrm{N}$ adsorption abilities [31], was selected as the skeleton material. Prior to use, the commercially-available zeolite 
mineral (Ø 1-2 mm), purchased from Yongjia Natural Minerals Ltd., Hebei, China, was passed through a 100-mesh sieve and washed three times with deionized water prior to drying at $105^{\circ} \mathrm{C}$ for 24 hours. In order to improve its $\mathrm{PO}_{4}{ }^{3-}-\mathrm{P}$ adsorption ability, the natural zeolite was modified using $\mathrm{NaOH}$ and $\mathrm{AlCl}_{3}$ before granulation. Specifically, the zeolite was immersed into $1 \mathrm{M} \mathrm{NaOH}$ (solid:liquid=1:6 w/w), stirred for $2 \mathrm{~h}$, and aged for $24 \mathrm{~h}$ at $25^{\circ} \mathrm{C}$. Precipitates were further washed three times with deionized water and then soaked in $1 \mathrm{M} \mathrm{AlCl}_{3}$ (solid: liquid=1:6 w/w), stirred again for $2 \mathrm{~h}$ and then aged for $24 \mathrm{~h}$. The resultant solid was then granulated into spherical particles $(\varnothing 3-5 \mathrm{~mm})$ by ball mill (LG-120A, China). After drying in air, the particles were transferred to a furnace and calcined at $800^{\circ} \mathrm{C}\left(10^{\circ} \mathrm{C} \mathrm{min}^{-1}\right.$ heating rate $)$ for $3 \mathrm{~h}$ under flowing $\mathrm{N}_{2}$.

After obtaining the aforementioned modified zeolite, the multifunctional geoengineering material (MFG) was further prepared by loading the $\mathrm{O}_{2}$ nanobubbles following the pressure swing adsorption method [27]. The details of the preparation procedure is shown in the Supporting Information.

\subsection{Materials characterization}

The textural properties including surface areas and pore volumes of both natural and modified zeolites were determined by the Brunauer-Emmett-Teller (BET) method using a Micromeritics ASAP 2020 instrument (Micromeritics, Inc., Noreross, USA). Xray photoelectron spectra (XPS; ESCALAB250Xi, ThermoFisher Scientific, Waltham, USA) was used to determine the major components of the two materials. Surface morphologies of the samples were observed by scanning electron microscope (SEM; JSM-6700F, JEOL Ltd., Tokyo Japan). The surface chemical properties were analysed 
using Fourier Transform Infrared spectroscopy (FT-IR; Tensor27, Bruker Corp., Billerica, USA), scanning OVER the range $4000-400 \mathrm{~cm}^{-1}$. X-ray powder diffraction (XRD) was performed using an X' Pert Pro MPD X-ray Diffractometer (Philips NV, Amsterdam, Netherlands) in order to determine mineral compositions.

\subsection{Evaluation of nutrient adsorption capabilities}

Adsorption isotherms of $\mathrm{PO}_{4}{ }^{3-}-\mathrm{P}$ were determined in Erlenmeyer flasks $(100 \mathrm{ml})$ by mixing various concentrations of $\mathrm{KH}_{2} \mathrm{PO}_{4}$ solutions with $0.5 \mathrm{~g}$ of natural or modified zeolites, respectively, with addition of $0.01 \mathrm{M} \mathrm{NaCl}$ to maintain the ionic strength. The mixtures were then agitated $\left(25^{\circ} \mathrm{C}, 200 \mathrm{rpm}, 24 \mathrm{~h}\right)$ allowing the adsorption to reach equilibrium. After $24 \mathrm{~h}$, the suspensions were filtered $(0.45 \mu \mathrm{m}$ membrane) for the determination of $\mathrm{PO}_{4}{ }^{3-}-\mathrm{P}$ by the molybdenum-blue ascorbic acid method. The adsorption isotherms of $\mathrm{NH}_{4}{ }^{+}-\mathrm{N}$ were determined by the same procedure, except that $\mathrm{NH}_{4} \mathrm{Cl}$ solution was used, instead of $\mathrm{KH}_{2} \mathrm{PO}_{4}$. Each experiment was conducted at $\mathrm{pH} 7.0$ and repeated three times.

\subsection{Determination of Oxygen-loading capability}

The $\mathrm{O}_{2}$ adsorption capacities of both natural and modified zeolites were determined by Temperature Programmed Desorption ( $\mathrm{O}_{2}$-TPD; Chemisorb 2720, Micromeritics Inc., Noreross, USA). During the test, the material $(10 \mathrm{mg})$ was placed in a quartz microreactor and treated with pure $\mathrm{O}_{2}$ at $600^{\circ} \mathrm{C}$ for $1 \mathrm{~h}$ until the material was saturated. It was then cooled to $50^{\circ} \mathrm{C}$ under flowing $\mathrm{O}_{2}$, and the gas switched to helium for $30 \mathrm{~min}$ in order to purge the $\mathrm{O}_{2}$ gas from the reactor. Subsequently, the $\mathrm{O}_{2}$ desorption process was carried out at $600^{\circ} \mathrm{C}$ with helium as the purge $\left(40 \mathrm{ml} \mathrm{min}{ }^{-1}\right.$; temperature increase $\left.10^{\circ} \mathrm{C} \mathrm{min}^{-1}\right)$. 
The $\mathrm{O}_{2}$ signal, detected by thermal conductivity detector (TCD), thus tracked the dynamics of $\mathrm{O}_{2}$ release from the zeolite materials. In order to quantify the amount of oxygen desorbed from the materials, thermogravimetric analysis (TGA; Seteram, Caluire-et-Cuire, France) was performed, to determine the mass lost from the materials during the desorption process. Firstly, $10 \mathrm{mg}$ of material was placed in a platinum TGA pan and saturated with $\mathrm{O}_{2}$ gas until a constant mass was recorded. Then, $\mathrm{N}_{2}$ gas (25 $\mathrm{mL} / \mathrm{min}$ ) was substituted and the material gradually heated to $800^{\circ} \mathrm{C}$ at $10{ }^{\circ} \mathrm{C} / \mathrm{min}$. A vacuum was then applied to the instrument and maintained for 300 mins. The dynamics of changes in sample mass were recorded.

\subsection{In-situ lake experiment}

An in-situ experiment was carried out in July and August (35 days), in a shallow eutrophic lake, located at Suzhou Street in Beijing, China (3959'N, 116 $16^{\circ}$ E; Fig. 1a). The lake has a total surface area of 220 ha, average depth of $1.8 \mathrm{~m}$ and suffered annually from eutrophication, especially in the summer months. Eight tubes, each with a $20-\mathrm{cm}$ inner diameter and height of $160 \mathrm{~cm}$, were employed, and inserted into the sediment of the lake to form $120 \mathrm{~cm}$ deep water columns and $30 \mathrm{~cm}$ sediment cores (Fig. 1a). Duplicate control groups, and those containing capping treatments by natural zeolite, modified zeolite and the multifunctional geoengineering material (MFG), were constructed. After 2 days' stabilization period, the different treatment materials (each of ca. $50 \mathrm{~g}$ ) were applied in respective columns, resulting in a 1-2 $\mathrm{cm}$ depth capping layer above the surficial sediment (Fig. 1b). Two extra columns were inserted as spares in case any columns were demaged (maybe by the fishes) or fell down during the course of the 
experiment.
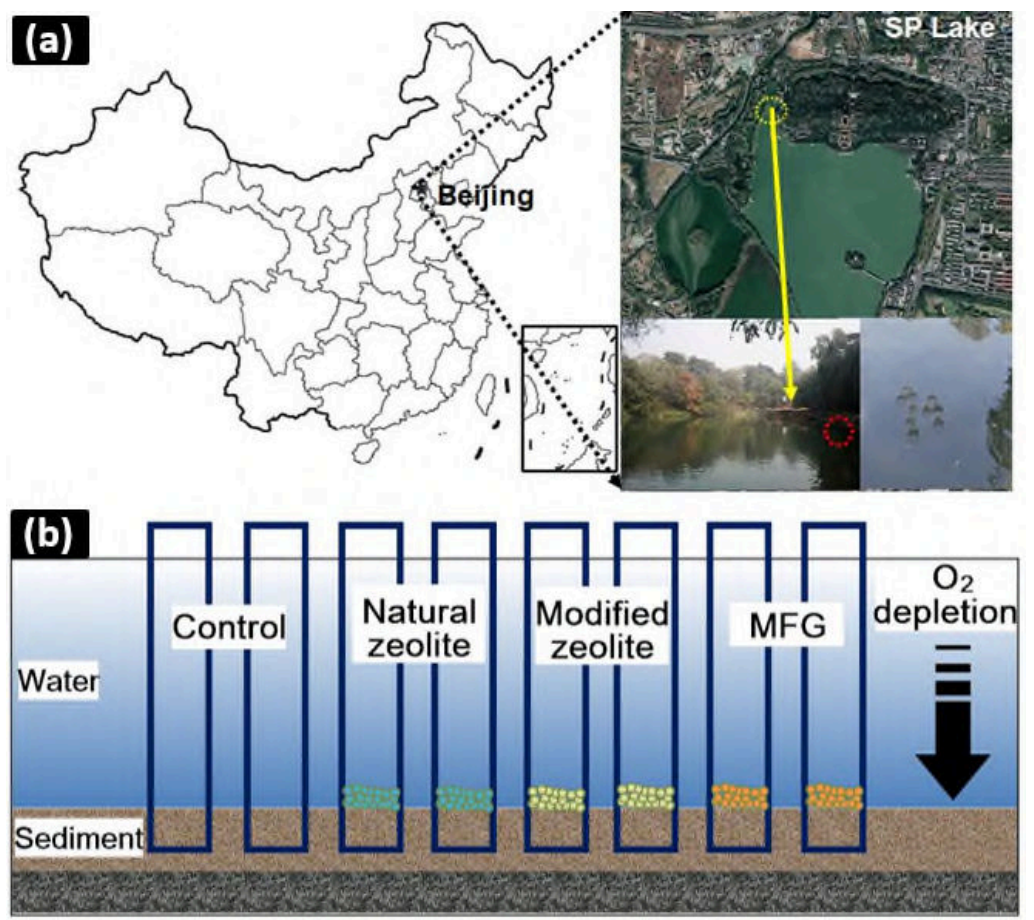

Fig. 1. Location of the in-situ experiment in a eutrophic shallow lake (a), and schematic description (b) of the columns. MFG (multifunction geoengineering material) represents the $\mathrm{O}_{2}$ nanobubble loaded modified zeolite.

During the experiment, overlying water samples $(100 \mathrm{~mL})$ from each column were carefully collected from $5 \mathrm{~cm}$ above the sediment using a peristaltic pump at day $1,3,5$, $7,10,13,16,19,21,25,28,31$, and 35 . The DO and ORP were measured in-situ concurrently with the sampling activities using a Yellow Springs Instruments Proplus meter (YSI, Ohio, USA). Nutrient concentrations in the collected water samples were measured (TP, $\mathrm{PO}_{4}{ }^{3-}-\mathrm{P}, \mathrm{TN}, \mathrm{NH}_{4}{ }^{+}-\mathrm{N}, \mathrm{NO}_{3}{ }^{-}-\mathrm{N}$, and $\left.\mathrm{NO}_{2}{ }^{-}-\mathrm{N}\right)$. After each sample collection, all columns were slowly replenished with lake water to compensate for sampling losses. Detailed methods for determining nutrient concentrations and cumulative fluxes calculation are presented in the Supporting Information.

In order to study the dynamics of composition of the benthic microbial community, 
surface sediment samples ( $1 \mathrm{~g} ; \sim 5 \mathrm{~cm}$ depth) were taken in triplicate from each column before and after the experiment, and microbial DNA was extracted using a FastDNA Soil DNA Kit (Omega Bio-tek, Norcross, USA), based on the manufacturer's recommendations. The V3-V4 hypervariable region of the 16S rRNA gene was amplified using $\quad 338 \mathrm{~F} \quad\left(5^{\prime}\right.$-ACTCCTACGGGAGGCAGCAG-3') and 806R (5'GGACTACHVGGGTWTCTAAT-3') primers, respectively. PCR amplification was performed by a GeneAmp® PCR System 9700 (Applied Biosystems, Foster City, USA) and the purified amplicons were sequenced with the MiSeq PE300 platform (Illumina, San Diego, USA). Dynamics of compositional changes in microbial communities in the sediment before and after treatment were compared through diversity indices, Redundancy analysis (RDA), and Principal Coordinate Analysis (PCoA). More details about the 16S rRNA gene sequence analysis could be found in the Supporting Information.

\subsection{Statistical analysis}

SPSS 19.0 (IBM Corporation, Armonk, NY, USA) and Origin 8.5 (OriginLab, Northampton, MA, USA) were used to analyse and plot the data, respectively. A one-way ANOVA and post-hoc Duncan's multiple range test were used to compare $(\mathrm{p}<0.05)$ water quality parameters between different treatment systems at each sampling point.

\section{Results}

\subsection{Multifunctional geoengineering material characterisations}

Porosity and composition. The BET surface area $\left(52.86 \mathrm{~m}^{2} / \mathrm{g}\right)$ and pore volume $\left(0.22 \mathrm{~cm}^{3} / \mathrm{g}\right)$ of the modified zeolite were significantly higher than those of natural zeolite, $\left(38.07 \mathrm{~m}^{2} / \mathrm{g}\right.$ and $0.06 \mathrm{~cm}^{3} / \mathrm{g}$, respectively; Table 1$)$. Moreover, the modification by $\mathrm{AlCl}_{3}$ 
addition led to a significantly higher content of aluminium (Al) in the modified zeolite $(23.37 \mathrm{wt} \%)$ than that $(13.87 \mathrm{wt} \%)$ in the natural zeolite.

Table 1

The general characteristics of natural zeolite (N-Z) and modified zeolite (M-Z).

\begin{tabular}{lllllll}
\hline Materials & $\begin{array}{l}\text { Fe } \\
(\mathbf{w t} \%)\end{array}$ & $\begin{array}{l}\text { Al } \\
(\mathbf{w t} \%)\end{array}$ & $\begin{array}{l}\text { Si } \\
(\mathbf{w t} \%)\end{array}$ & $\begin{array}{l}\text { Surface } \\
\mathbf{a r e a}\left(\mathbf{m}^{2} / \mathbf{g}\right)\end{array}$ & $\begin{array}{l}\text { Pore volume } \\
\left(\mathbf{c m}^{3} / \mathbf{g}\right)\end{array}$ & $\begin{array}{l}\text { Pore diameter } \\
(\mathbf{n m})\end{array}$ \\
\hline Natural zeolite & 5.39 & 13.87 & 52.75 & 38.07 & 0.06 & 6.40 \\
Modified zeolite & 6.25 & 23.37 & 49.5 & 52.86 & 0.22 & 9.08 \\
\hline
\end{tabular}

Morphology and characteristics. The morphology of the natural zeolite appeared amorphous and coarse, with many protrusions (Fig. 2a), however, the modified zeolite showed clear differences with many needle-shaped particles apparent (Fig. 2b). In the XRD pattern (Fig. 2c), the positions of the main signals for natural and modified zeolites were similar, which indicated that the modification process did not destroy the fundamental zeolite structure. However, some new signals appeared in the pattern for the modified zeolite at $2 \theta=12.86^{\circ}, 26.58^{\circ}, 31.76^{\circ}$, which are characteristic for $\mathrm{AlCl}_{3}(\mathrm{Jade}$ software; Materials Data Inc., Livermore, USA). In the FT-IR spectrum (Fig. 2d), broad band hydration signals, centred on 3447,1638 and $1634 \mathrm{~cm}^{-1}$ are characteristic of the hydroxyl group [33], with the stretching and bending vibrations due to adsorbed water. The intensities of the structural $\mathrm{OH}$ bands decreased in the spectrum obtained from the modified zeolite, which was an indication that physically absorbed water had been lost and that the structure had been partially destroyed, changes induced by calcination. The bands characteristic of Si-O bonds $\left(1099,1095\right.$ and $\left.1091 \mathrm{~cm}^{-1}\right)$ appeared in both zeolites, indicated that the silicate minerals had been highly resistant to modification under high temperature [34]. Once again, the band at $793 \mathrm{~cm}^{-1}$, corresponding to Al-O-Al stretching 
vibrations, only appeared in the modified zeolite.
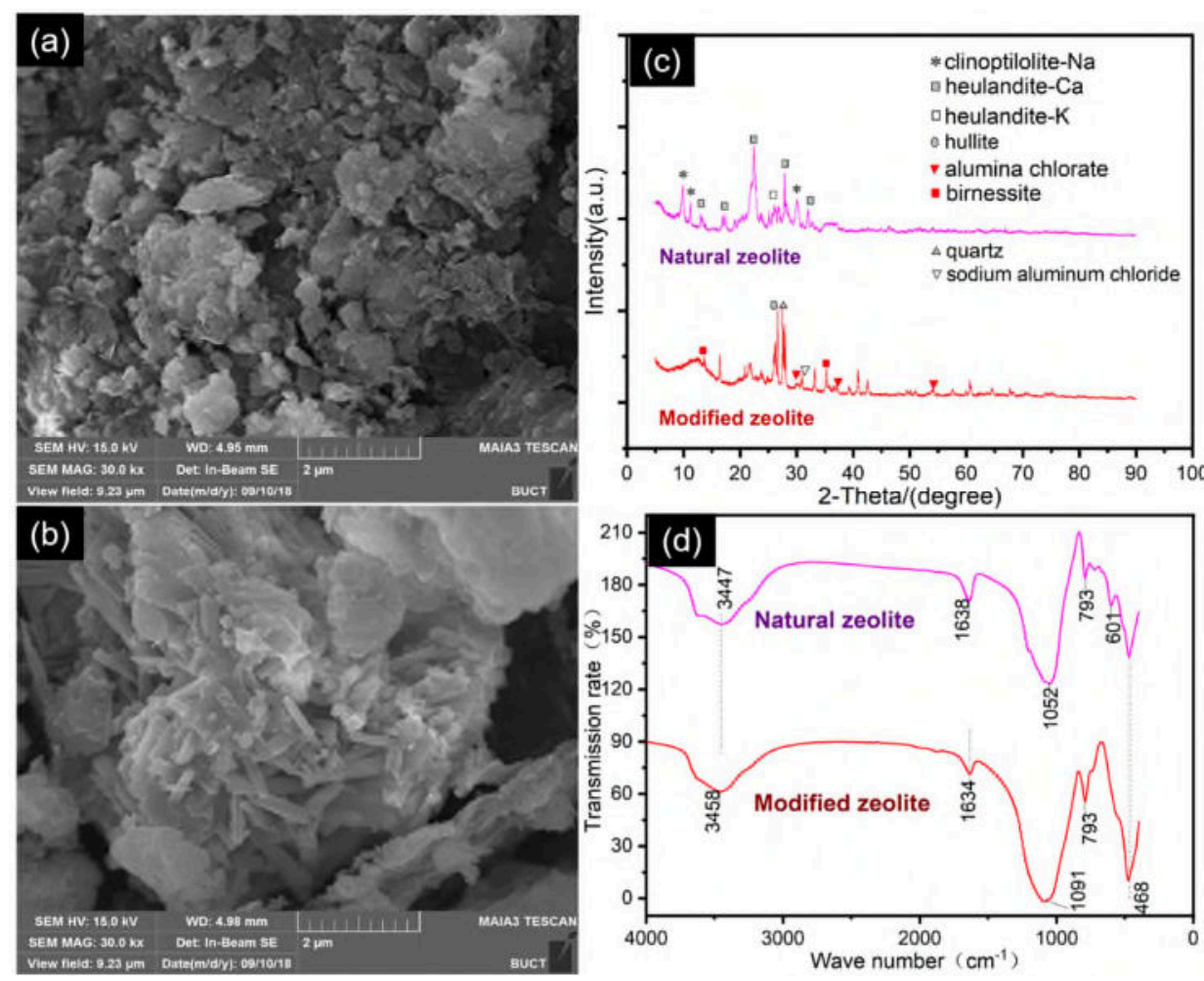

Fig. 2. Scanning electron microscope (SEM) images of natural (a) and modified (b) zeolites, and their characterisation by X-ray powder diffraction (XRD, c) and Fourier Transform infrared spectrum (FT-IR, d). The SEM image was acquired under In-Beam SE mode with accelerating voltage (HV) and magnification (MAG) of $15 \mathrm{kV}$ and $30 \mathrm{kx}$, respectively.

Adsorption isotherms and $\mathrm{O}_{2}$ loading capacity. The adsorption isotherms of $\mathrm{PO}_{4}{ }^{3-}-\mathrm{P}$ and $\mathrm{NH}_{4}{ }^{+}-\mathrm{N}$ for both natural and modified zeolites exhibited L-shape curves (Fig. 3a and b), which all fitted the Langmuir model $\left(\mathrm{R}^{2}>0.992\right.$, Table S1). Significantly higher $\mathrm{P}$ adsorption capacity $\left(\mathrm{Q}_{\mathrm{m}} 4.38 \mathrm{mg} / \mathrm{g}\right)$ was achieved by the modified zeolite compared with that $\left(\mathrm{Q}_{\mathrm{m}} 1.05 \mathrm{mg} / \mathrm{g}\right)$ by natural zeolite. Likewise, the modified zeolite possessed enhanced capability for $\mathrm{N}$ adsorption $\left(\mathrm{Q}_{\mathrm{m}} 9.81 \mathrm{mg} / \mathrm{g}\right)$ compared with that $\left(\mathrm{Q}_{\mathrm{m}} 6.29 \mathrm{mg} / \mathrm{g}\right)$ for natural zeolite.

The $\mathrm{O}_{2}$-TPD traces (Fig. 3c) clearly exhibited significantly larger desorption peaks 
for the modified zeolite than those of natural zeolite in the temperature ranges of 50$250^{\circ} \mathrm{C}$ and $300-600^{\circ} \mathrm{C}$, respectively. Integration of the desorption traces indicated that the total peak area of $\mathrm{O}_{2}$ desorbed from modified zeolites was around 20 -fold higher than that from natural zeolites. The results of thermogravimetric analyses (TGA) generally agreed with the relevant $\mathrm{O}_{2}$-TPD data (Fig. 3d), where a smaller mass loss occurred at lower temperatures $\left(<250^{\circ} \mathrm{C}\right)$ but considerable mass loss arose from for both materials when the temperature rose above $300^{\circ} \mathrm{C}$. Notably, calcination and pre-drying treatments could theoretically minimize the content of the adhered water and crystalline components [35]. Thus, the $\mathrm{O}_{2}$ desorbed at lower temperatures would have been caused mainly by the physical adsorption of $\mathrm{O}_{2}$ by the materials [36]. The $\mathrm{O}_{2}$ mass loss at high temperatures was due to that chemisorbed by the materials. During the entire test, the modified zeolite was demonstrated to carry $121 \mathrm{mg} \mathrm{O}_{2} / \mathrm{g}$, which was 2.6 times higher than that $(46 \mathrm{mg} \mathrm{O} 2$ $/ g$ ) observed from the natural zeolite, based on the mass loss during $\mathrm{O}_{2}$ desorption. 

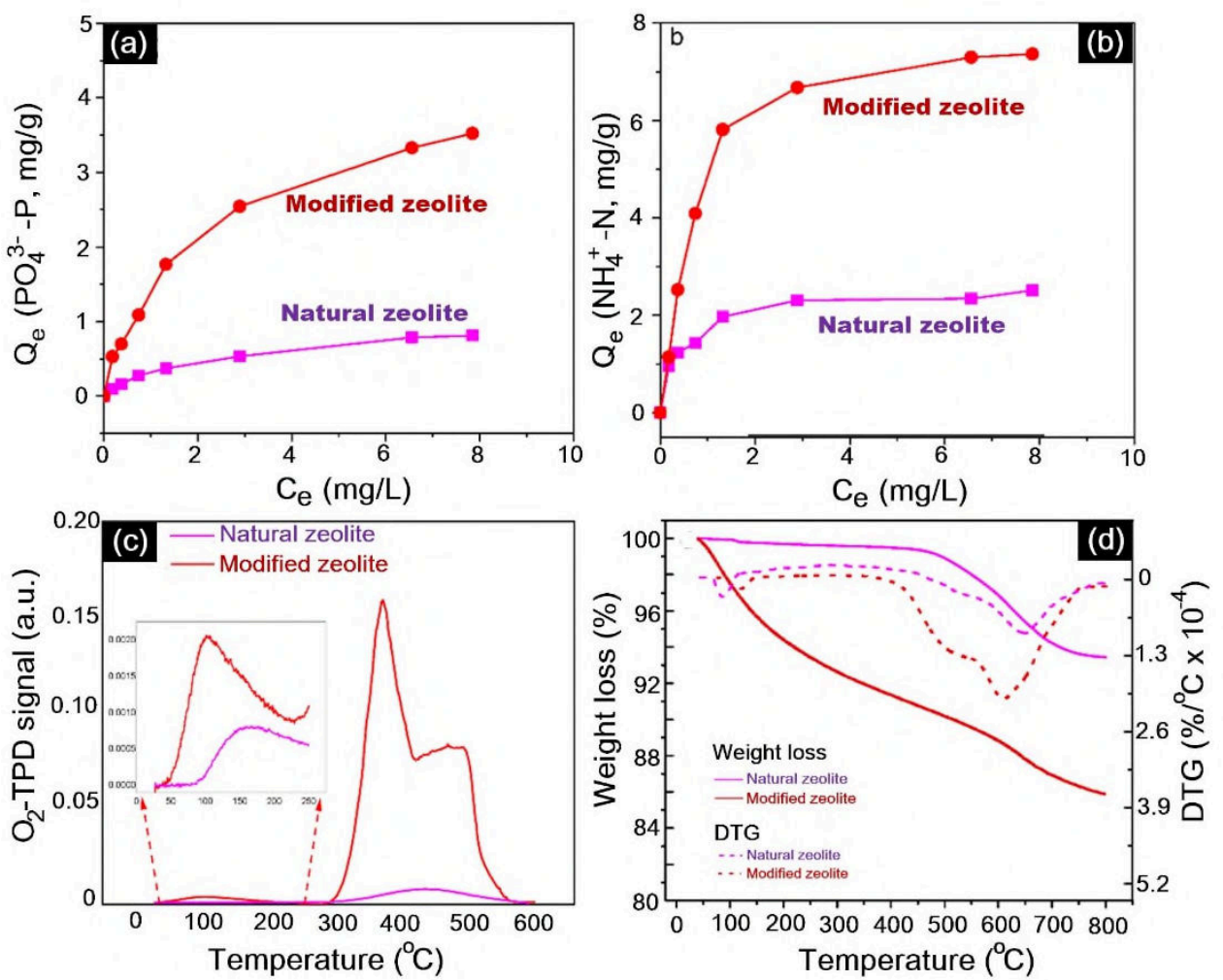

Fig. 3. Phosphate (a) and ammonium (b) adsorption isotherms of natural and modified zeolites. Temperature Programmed Desorption patterns $\left(\mathrm{O}_{2}-\mathrm{TPD}, \mathrm{c}\right)$ and the thermogravimetric analysis (Thermogravimetry(TG)-Differential Thermogravimetry (DTG) curves, d) from the $\mathrm{O}_{2}$ adsorption capability test.

\subsection{In-situ experiment evaluation}

DO and ORP dynamics of the overlying water. The in-situ experiment was conducted in a shallow eutrophic lake. The levels of DO and ORP of the overlying water ( $5 \mathrm{~cm}$ above the sediment) were around $1.5 \mathrm{mg} / \mathrm{L}$ and $-200 \mathrm{mV}$, respectively, in the control system throughout the experiment (Fig. 4a and b). The natural zeolite capping treatment managed to slightly increase DO to $2 \mathrm{mg} / \mathrm{L}$ and ORP levels to $-100 \mathrm{mV}$. The modified zeolite, without $\mathrm{O}_{2}$ nanobubble loading, was observed to increase DO and ORP levels to $3.3 \mathrm{mg} / \mathrm{L}$ and $-50 \mathrm{mV}$ from day 9 , respectively. However, in the groups capped with the multifunctional geoengineering material (MFG), the DO within overlying waters rapidly 
increased from 1.5 to $6.2 \mathrm{mg} / \mathrm{L}$, and the ORP from -200 to $175 \mathrm{mV}$, in the first 5 days and these values remained stable until the end of the experiment.
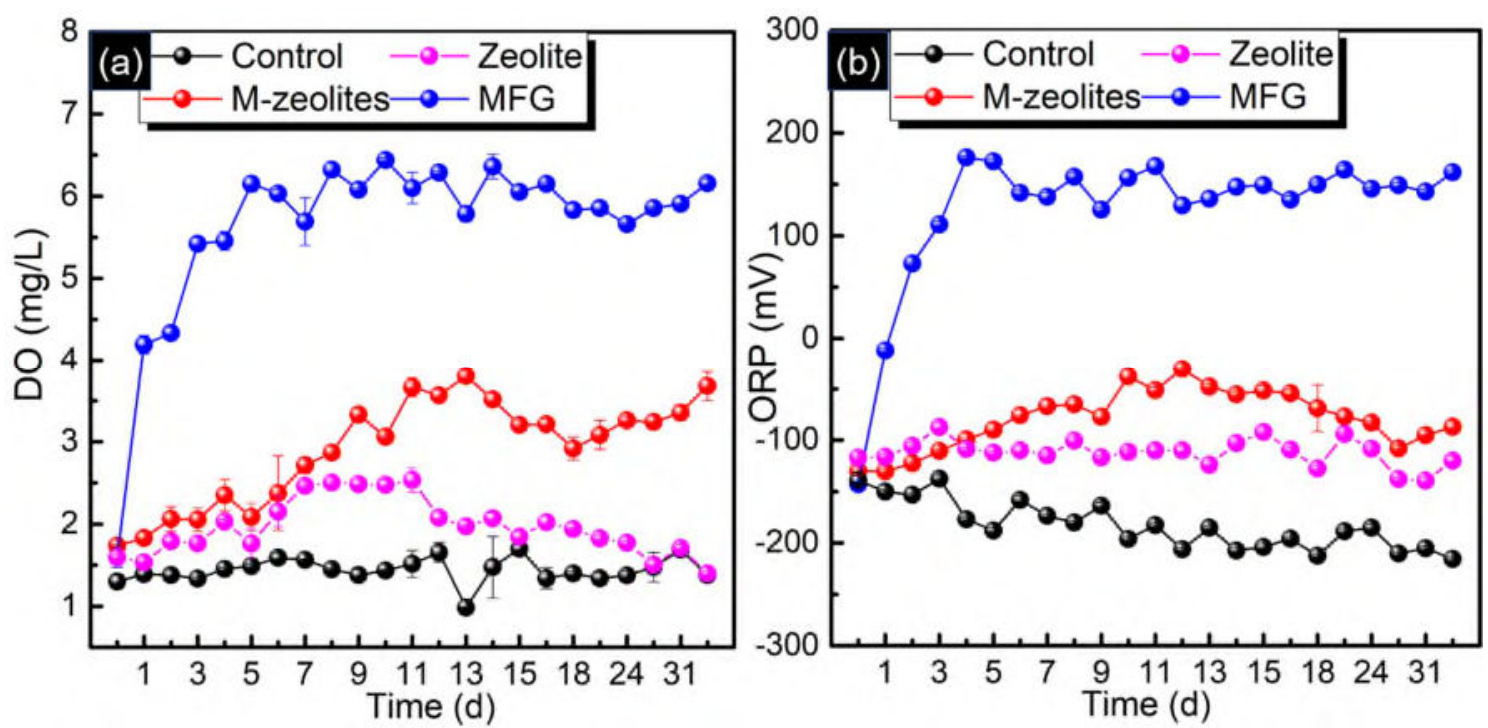

Fig. 4. Dynamics of DO (a) and ORP (b) at the SWI in different treatment systems. Zeolite and M-zeolite represent natural and modified zeolites, respectively. MFG (multifunction geoengineering material) represents the $\mathrm{O}_{2}$ nanobubble-loaded modified zeolite.

Nutrient dynamics and cumulative nutrient flux at SWI. The continual lower DO/ORP levels in the control systems (Fig. 4) led to gradually increased concentrations of $\mathrm{PO}_{4}{ }^{3-}-\mathrm{P}$ and $\mathrm{NH}_{4}{ }^{+}-\mathrm{N}$ within overlying waters, which attained around 0.085 and 0.56 $\mathrm{mg} / \mathrm{L}$, respectively (Fig. 5a and b). Based on calculations, the cumulative fluxes of nutrients from sediment to overlying water showed positive values of $1.9-6.8 \mathrm{mg} / \mathrm{m}^{2} / \mathrm{d}$ for $\mathrm{PO}_{4}{ }^{3-}-\mathrm{P}$, and 4.8-19.7 mg/m² $/ \mathrm{d}$ for $\mathrm{NH}_{4}{ }^{+}-\mathrm{N}$ (Fig. 5c and d) throughout the duration of the experiment.

The concentrations of $\mathrm{PO}_{4}{ }^{3-}-\mathrm{P}$ in overlying water were significantly lower in the MFG treatment groups $(\sim 0.02 \mathrm{mg} / \mathrm{L})$, compared with those values from the modified ( $\sim 0.06 \mathrm{mg} / \mathrm{L})$ and natural ( $\sim 0.075 \mathrm{mg} / \mathrm{L})$ zeolite groups (Fig. 5a). Only the MFG treatment group yielded a negative cumulative $\mathrm{PO}_{4}{ }^{3-}-\mathrm{P}$ flux $\left(-1.69\right.$ to $\left.-0.34 \mathrm{mg} / \mathrm{m}^{2} / \mathrm{d}\right)$ compared with 
the other groups (Fig. 5c). The dynamics of $\mathrm{NH}_{4}{ }^{+}-\mathrm{N}$ in the overlying waters were generally similar to those for $\mathrm{PO}_{4}{ }^{3-}-\mathrm{P}$ and followed the order MFG $>$ modified zeolite $\geq$ natural zeolite $>$ control systems (Fig. 5b). Both modified and natural zeolite treatments functioned similarly to reduce the $\mathrm{NH}_{4}{ }^{+}-\mathrm{N}$ concentration in overlying water $(\sim 0.4 \mathrm{mg} / \mathrm{L}$ at day 35) and cumulative flux $\left(\sim 3.65 \mathrm{mg} / \mathrm{m}^{2} / \mathrm{d}\right)$ through the SWI. However, $\mathrm{NH}_{4}{ }^{+}-\mathrm{N}$ concentrations and the cumulative flux attained approximately $0.25 \mathrm{mg} / \mathrm{L}$ (day 35) and $5 \mathrm{mg} / \mathrm{m}^{2} / \mathrm{d}$, respectively, in the MFG-treated groups (Fig. $5 \mathrm{~b}$ and d).
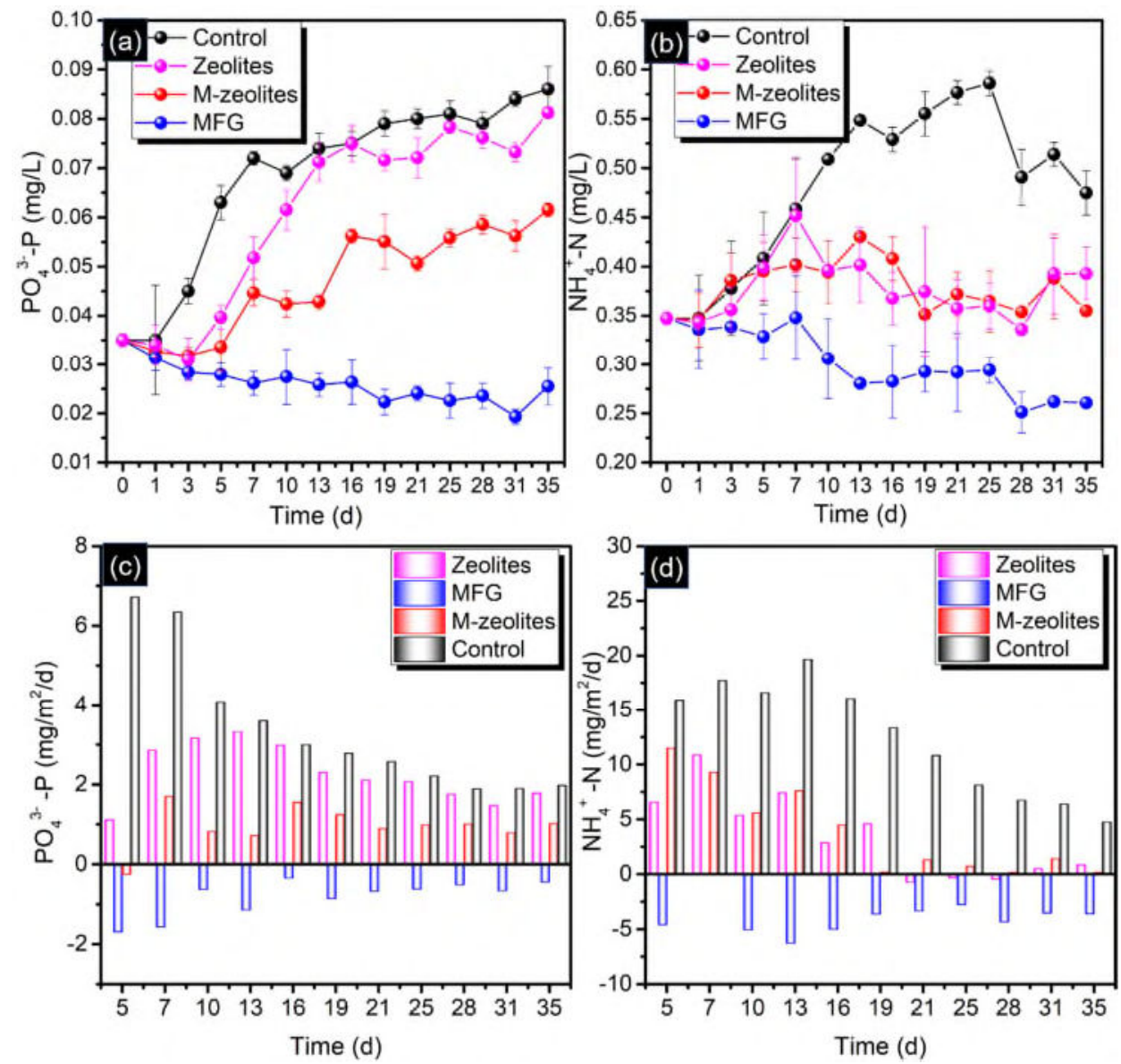

Fig. 5. Dynamics of $\mathrm{PO}_{4}{ }^{3-}-\mathrm{P}(\mathrm{a})$ and $\mathrm{NH}_{4}{ }^{+}-\mathrm{N}$ (b) in the overlaying water, and cumulative fluxes of $\mathrm{PO}_{4}{ }^{3-}-\mathrm{P}(\mathrm{c})$ and $\mathrm{NH}_{4}{ }^{+}-\mathrm{N}(\mathrm{d})$ across the SWI in each system. Zeolite and M-zeolite represent natural and modified zeolites, respectively. MFG (multifunction geoengineering material) represents the $\mathrm{O}_{2}$ nanobubble-loaded modified zeolite.

Quantitative analysis of the contributions of different functionalities to internal 
nutrient load control. Mass balance calculations, using to the cumulative nutrient fluxes, were carried to quantify the relevant contributions of different functionalities, i.e. capping treatment, modification to improve nutrient adsorption, and $\mathrm{O}_{2}$ delivery, on internal nutrient load control (Fig. 6). The highest amounts of $\mathrm{PO}_{4}{ }^{3-}-\mathrm{P}$ and $\mathrm{NH}_{4}{ }^{+}-\mathrm{N}$ released from sediment throughout the 35-day experiment, were $2.93 \mathrm{mg}$ (Fig. 6a1) and $11.42 \mathrm{mg}$ (Fig. 6b1) respectively, , occurring in the control mesocosms. After treatment by the natural zeolites, the amounts released decreased to $2.21 \mathrm{mg} \mathrm{PO}_{4}{ }^{3-}-\mathrm{P}$ and $2.90 \mathrm{mg} \mathrm{NH}_{4}{ }^{+}-\mathrm{N}$. The results indicated that, in isolation, the capping treatment utilising only natural zeolites, could reduce the release of $\mathrm{PO}_{4}{ }^{3-}-\mathrm{P}$ and $\mathrm{NH}_{4}{ }^{+}-\mathrm{N}$ by around $24.6 \%$ and $74.6 \%$, respectively (Fig. $6 \mathrm{a} 2$ and b2). The internal loading of $\mathrm{PO}_{4}{ }^{3-}-\mathrm{P}$ in the system treated by the modified zeolites was $0.96 \mathrm{mg}$. After subtracting the contribution from the capping treatment alone, the modified zeolite could furnish a further reduction of $42.7 \%$ in the release of $\mathrm{PO}_{4}{ }^{3-}-\mathrm{P}$ (Fig. 6a3). However, this modification only contributed a further $0.4 \%$ reduction for control of the internal $\mathrm{NH}_{4}{ }^{+}-\mathrm{N}$ loading. Both $\mathrm{PO}_{4}{ }^{3-}-\mathrm{P}$ and $\mathrm{NH}_{4}{ }^{+}-\mathrm{N}$ fluxes were totally reversed in the MFG-treated groups (Fig. 5c and d) and the total masses fixed were 0.72 $\mathrm{mg}$ and $3.55 \mathrm{mg}$, respectively (Fig. $6 \mathrm{a} 4$ and b4), substantially changing the sediment from a nutrient source to a sink. In addition to zeolite capping and modification, the effect of the $\mathrm{O}_{2}$ nanobubble oxidation contributed further reductions of $57.3 \% \mathrm{PO}_{4}{ }^{3-}-\mathrm{P}$ and $56.1 \%$ $\mathrm{NH}_{4}{ }^{+}-\mathrm{N}$, compared with the control systems.

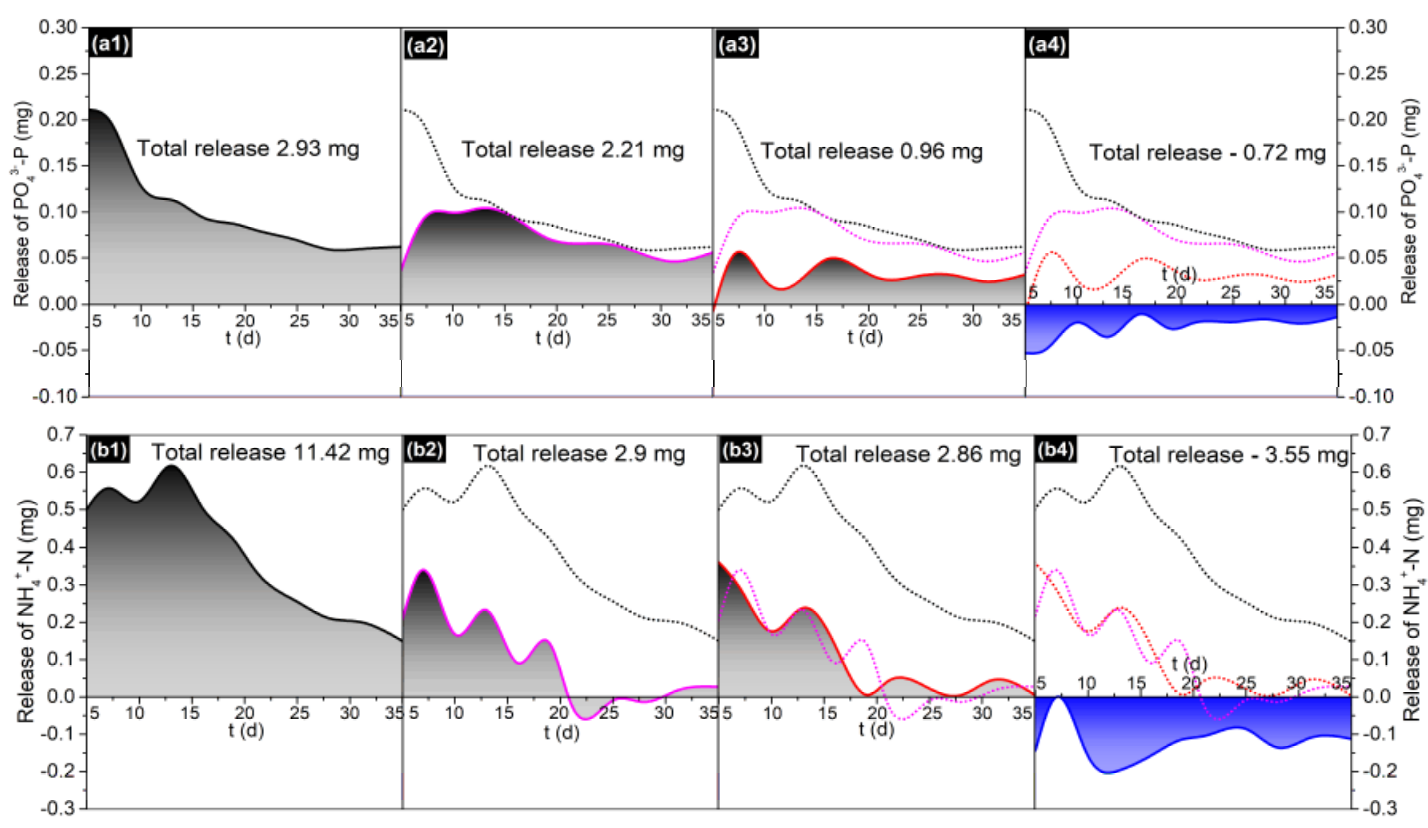


Fig. 6. Quantitative analysis of the treatment by natural zeolite ( $a 2$ and b2), modified zeolite (a3 and b3) and MFG (a4 and b4) for internal $\mathrm{PO}_{4}{ }^{3-}-\mathrm{P}(\mathrm{a})$ and $\mathrm{NH}_{4}{ }^{+}-\mathrm{N}$ (b) releases compared with the control systems (a1 and b1). The black, pink, red, and blue lines refer to internal nutrients $\left(\mathrm{PO}_{4}{ }^{3-}\right.$ -P (a) and $\mathrm{NH}_{4}{ }^{+}-\mathrm{N}(\mathrm{b})$ releases in control systems, natural zeolite, modified zeolite, and MFG systems, respectively. MFG (multifunction geoengineering material) represents the $\mathrm{O}_{2}$ nanobubble-loaded modified zeolite.

Alterations in microbial community composition. Sediment microbial community compositions in all four systems were analysed at the beginning and end of the experiment for comparison. After quality trimming, a total of 11,455 OTUs belonging to 60 phyla and 1,319 genera were extracted from 24 samples and the Good's coverage estimator of over $95 \%$ suggested that most of bacterial OTUs in each sample had been captured (Table S2). The highest microbial diversity (Shannon and Simpson index values) in the group after the MFG treatment indicated that $\mathrm{O}_{2}$ nanobubbles could support a rich and diverse consortium for the biotransformation of nutrients, by establishing more complex oxygen gradients for bacterial survival, potentially resulting in the observed reductions in $\mathrm{PO}_{4}{ }^{3-}-\mathrm{P}$ and $\mathrm{NH}_{4}{ }^{+}-\mathrm{N}$ release from the sediment.

The microbial communities showed high diversity at the phylum level with the major phyla being identified as Proteobacteria, Chloroflexi, Actinobacteria, Acidobacteria, Bacteroidetes, Firmicutes, Nitrospirae, Latescibacteria, Patescibacteria and Spirochaetes (Fig. 7a). The in-situ samples for all systems showed certain variation, thus the microbial community changes were specifically compared between each system before and after the treatment (Fig. S1). The proportions of Actinobacteria, Acidobacteria and Nitrospirae significantly improved in the total abundance of bacteria in the sediment 
after treatment by MFG, compared with those in the control groups (Fig. S1). All three phyla were found to belong to typical ammonia oxidizing bacteria, which work in the nitrification process by transforming $\mathrm{NH}_{4}{ }^{+}-\mathrm{N}$ to $\mathrm{NO}_{2}{ }^{-}-\mathrm{N}$ and then to $\mathrm{NO}_{3}{ }^{-}-\mathrm{N}$ [40]. The MFG treatment groups in the RDA plot were clearly separated from the other systems (Fig. 7b), and DO was calculated to be the main driving factor $(\mathrm{p}<0.05)$ to differentiate the microbial community in MFG-treated groups (Table S3).
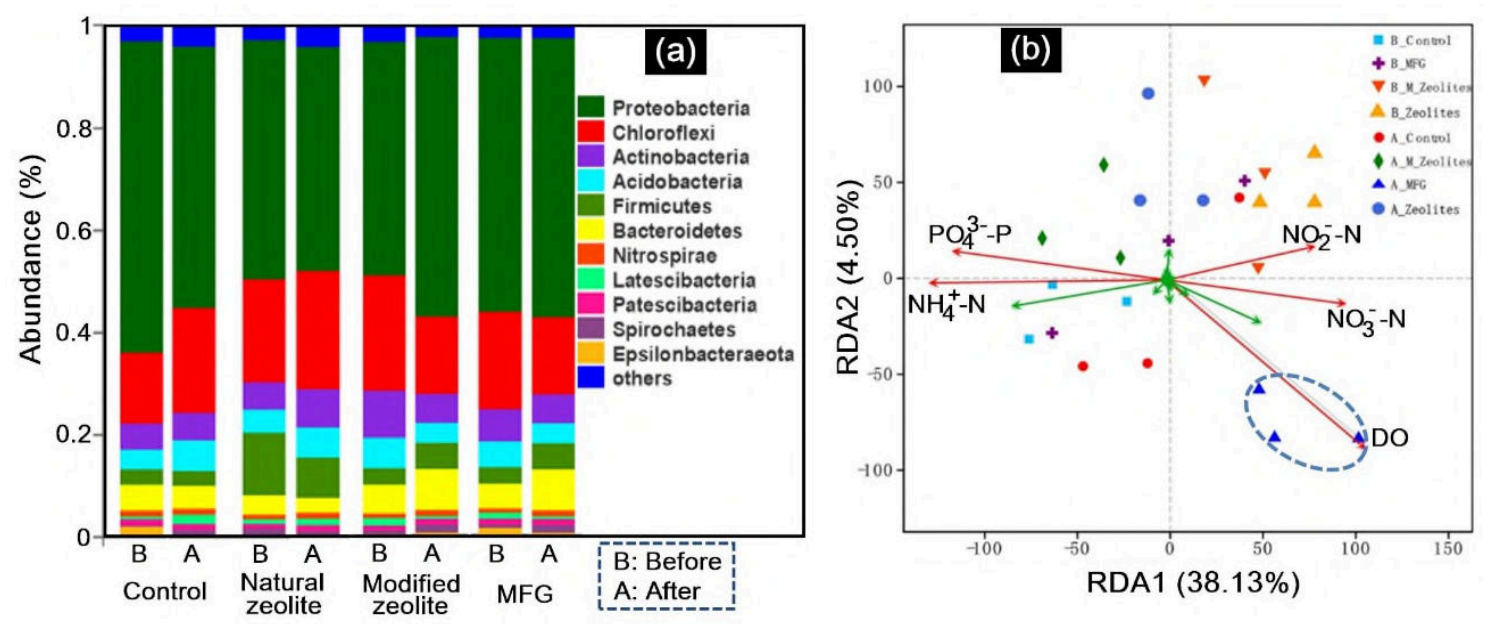

Fig. 7. Taxonomic classification of bacterial $16 \mathrm{~S}$ rDNA gene reads of the sediment from the groups of control, natural zeolite, modified zeolite and MFG treatments at phylum level (a, relative abundances $<1 \%$ not shown). Redundancy analysis (RDA) plot (b) of relationships between environmental variables and bacterial community composition.

\section{Discussion}

\subsection{Enhanced abilities of nutrient adsorption and $\mathrm{O}_{2}$ delivery}

The zeolite modification, before loading the $\mathrm{O}_{2}$ nanobubbles, significantly increased the pore size and volume of the zeolite (Table 1), which may have been due to the calcination treatment at high temperature [31]. These morphologically modifications of the zeolite, including the improved pore volume and surface area (Fig. 2), led to an enhanced capability for $\mathrm{NH}_{4}{ }^{+}-\mathrm{N}$ adsorption $\left(\mathrm{Q}_{\mathrm{m}} 9.81 \mathrm{mg} / \mathrm{g}\right)$ compared with that of natural 
zeolite ( $\mathrm{Q}_{\mathrm{m}} 6.29 \mathrm{mg} / \mathrm{g}$, Fig. 3b). Moreover, aluminium (Al) has been widely used as an additive in the preparation of effective $\mathrm{PO}_{4}{ }^{3-}-\mathrm{P}$ adsorbents, because of its high affinity for $\mathrm{PO}_{4}{ }^{3-}-\mathrm{P}[32]$. The FTIR characteristics demonstrated the successful addition of Al into the modified zeolite (Fig. 2d). Therefore, significantly higher $\mathrm{PO}_{4}{ }^{3-}-\mathrm{P}$ adsorption capacity was achieved by the modified zeolite compared with that of natural zeolite (Fig. 3a). The enhanced nutrient adsorption capacities acted to fix more nutrients and thus led to a diminished release of nutrients from the sediment to the overlying water during the capping treatment.

The modified zeolite was demonstrated to be able to carry 2.6 times $\left(121 \mathrm{mg} \mathrm{\textrm {O } _ { 2 }} / \mathrm{g}\right)$ the amount of $\mathrm{O}_{2}$ compared with that $\left(46 \mathrm{mg} \mathrm{O}_{2} / \mathrm{g}\right.$ ) of natural zeolite (Fig. 3). The higher $\mathrm{O}_{2}$ loading capacity was consistent with the increased surface area and pore volume observed from the modified zeolite (Table 1), which further suggested that oxygen carrying capacity was more likely due to the existence of mesoporous voids in the capping material [37]. The results supported the hypothesis that the prepared multifunction geoengineering material (MFG), a $\mathrm{O}_{2}$ nanobubble-loaded modified zeolite, could carry more $\mathrm{O}_{2}$ nanobubbles and deliver them into the SWI to alleviate sediment hypoxia.

\subsection{Promoted efficiency of in situ sediment remediation}

Sediment hypoxia is a common phenomenon in eutrophic and/or highly polluted water bodies, where there is usually significant release of internal (i.e. sediment-borne) pollutants [18]. It is well known that release of both $\mathrm{P}$ and $\mathrm{N}$ from sediments can be significantly accelerated under hypoxic/anoxic conditions [19]. Thus, with reference to our in-situ lake experiments, the increased concentrations of $\mathrm{PO}_{4}{ }^{3-}-\mathrm{P}$ and $\mathrm{NH}_{4}{ }^{+}-\mathrm{N}$ within 
overlying waters were observed in the control systems with low DO/ORP levels (Fig. 5). The concentrations of TP $(0.097 \mathrm{mg} / \mathrm{L})$ and TN $(1.16 \mathrm{mg} / \mathrm{L}$, Fig. S2) in the control groups were clearly higher than the nutrient thresholds $(\mathrm{TP}<0.05 \mathrm{mg} / \mathrm{L}$ and $\mathrm{TN}<0.8 \mathrm{mg} / \mathrm{L}$ ) typically observed during the occurrence of HABs and eutrophication episodes in freshwaters [38].

After application of the capping material, the physical barrier thus formed above the sediment could stop release of anaerobic substances back to the water [13] and could be the reason that the natural zeolite capping treatment managed to slightly increase DO to $2 \mathrm{mg} / \mathrm{L}$ and ORP levels to $-100 \mathrm{mV}$ (Fig. 4). Moreover, the modified zeolite further increased the DO and ORP levels to $3.3 \mathrm{mg} / \mathrm{L}$ and $-50 \mathrm{mV}$, respectively, which may have been due to the presence of more micropores in the modified zeolites (Table1). The modified zeolite may also have incorporated air due to exposure to the atmosphere after the capping operation. This may have, in turn, activated more oxidised substances, such as iron oxide [28], thus resulting in a slightly higher oxidising environment than that present in the natural zeolite and control groups. In the groups capped with the MFG, significantly higher levels of DO $(6.2 \mathrm{mg} / \mathrm{L})$ and ORP $(175 \mathrm{mV})$ in the overlying waters were achieved (Fig. 4). The successful reversal from hypoxia at the SWI to aerobic conditions was attributed to the synergistic functionalities of the formation of a physical barrier by the capping material and prolonged, sustainable, $\mathrm{O}_{2}$ nanobubble delivery, and which were in accord with a previous study [27]. Under such interfacial $\mathrm{O}_{2}$ nanobubble treatment, nano-scale $(<200 \mathrm{~nm}) \mathrm{O}_{2}$ bubbles could be constantly released, forming an oxygen-locked layer at the SWI [27]. This mode of action is different from the traditional 
aeration methods of introducing large gas/oxygen bubbles. The $\mathrm{O}_{2}$ nanobubbles possess unique characteristics of long lifetimes and high gas dissolvability [26], therefore supporting the reversal of the initial conditions of hypoxia to the final aerobic status.

The enhanced control of nutrient flux (Fig. 5) by the modified zeolite may be attributable to the larger adsorption capacity for $\mathrm{PO}_{4}{ }^{3-}-\mathrm{P}$ than that observed from the natural zeolite, since the Al content in the modified zeolite particles (Fig. 2) could adsorb $\mathrm{PO}_{4}{ }^{3-}-\mathrm{P}$ through the formation of an insoluble phosphate $\left(\mathrm{Al}-\mathrm{PO}_{4}\right)$, precipitated onto the mineral surface [39]. Although the obvious change of Al content in modified zeolites in Table 1, the P adsorption capacity of aluminium modified zeolites, compared with natural zeolites, seemed insufficient to control the release of phosphorus from sediments (Fig.5a). This is mainly because the excessive release of $\mathrm{PO}_{4}{ }^{3-}-\mathrm{P}$ under the hypoxic conditions might have exceeded the adsorption efficiency of the modified zeolites (Fig.4). When extra $\mathrm{O}_{2}$ was delivered at the SWI by MFG, the $\mathrm{O}_{2}$ could actively change the valence of any metals present, such as iron for example, to facilitate formation of, in this case, Fe-P [28]. This could explain the significant higher efficiency of MFG in reducing $\mathrm{PO}_{4}{ }^{3-}-\mathrm{P}$ concentrations in the overlying water, and the $\mathrm{PO}_{4}{ }^{3-}-\mathrm{P}$ influx observed across the SWI.

Although the modified zeolites possessed significantly higher $\mathrm{NH}_{4}{ }^{+}-\mathrm{N}$ adsorption capacities than did the natural zeolite (Fig. 3b), both materials functioned similarly to reduce the $\mathrm{NH}_{4}{ }^{+}-\mathrm{N}$ concentration in overlying water $(\sim 0.4 \mathrm{mg} / \mathrm{L}$ at day 35$)$ and flux $(\sim 3.65$ $\mathrm{mg} / \mathrm{m}^{2} / \mathrm{d}$ ) through the SWI. This may have been due to the presence of co-existing, competitive, ions, such as $\mathrm{Na}^{+}, \mathrm{K}^{+}, \mathrm{Ca}^{2+}$, and $\mathrm{Mg}^{2+}$, that probably pre-existed in the sediment, which acted to dramatically reduce $\mathrm{NH}_{4}{ }^{+}-\mathrm{N}$ adsorption during the application 
of the capping material [36]. It is understood that the nitrification reaction could be stimulated under aerobic conditions [21], which might have been caused by the delivery of $\mathrm{O}_{2}$ nanobubbles and thus resulted in reduced $\mathrm{NH}_{4}{ }^{+}-\mathrm{N}$ release from the sediment back to the overlying water (Fig. 5b). The changed oxygen levels in MFG-treated groups could have affected $\mathrm{N}$ transformations mediated by bacterial activities at the SWI (Fig. 7), particularly nitrification, denitrification and anammox reactions. The significant enhancement in DO concentrations at the SWI after adding MFG accelerated the nitrification process, converting $\mathrm{NH}_{4}{ }^{+}-\mathrm{N}$ to $\mathrm{NO}_{3}{ }^{-}-\mathrm{N}$ [21], which was supported by the lower values of $\mathrm{NH}_{4}{ }^{+}-\mathrm{N}$, whereas higher levels of $\mathrm{NO}_{3}{ }^{-}-\mathrm{N}$ and $\mathrm{NO}_{2}^{-}-\mathrm{N}$, occurred in the groups treated by MFG during the experiment (Fig. S1). As a result, application of MFG effectively improved the water quality through regulating biogeochemical processes to reduce levels of $\mathrm{NH}_{4}{ }^{+}-\mathrm{N}$ in the water.

Both capping treatment [13] and $\mathrm{O}_{2}$ nanobubble technologies [27] have been previously demonstrated successfully for control of eutrophication. However, the quantitative contributions of capping treatment and hypoxia remediation are unclear. The quantitative analysis in this study demonstrated that the synthetic MFG could integrate all functionalities (i.e., physical capping, adsorption, and oxidation) and that its application transformed the sediment from a nutrient source to a sink through decreasing the cumulative $\mathrm{PO}_{4}{ }^{3-}-\mathrm{P}$ and $\mathrm{NH}_{4}{ }^{+}-\mathrm{N}$ fluxes by $124.6 \%$ and $131.1 \%$, respectively (Fig. 6). Moreover, $\mathrm{O}_{2}$ nanobubble delivery was determined to be the largest contributor, which reduced $57.3 \%$ and $56.1 \%$ of the fluxes of $\mathrm{PO}_{4}{ }^{3-}-\mathrm{P}$ and $\mathrm{NH}_{4}{ }^{+}-\mathrm{N}$, respectively.

\subsection{Environmental implications}


Although an ever-increasing arsenal of geo-engineering materials is currently available for eutrophication control, cost-efficient and ecologically benign materials are still in urgent demand [41]. The estimated costs of some readily-available commercial Pcapping materials range between $€ 0.3$ million and $€ 0.8$ million per $\mathrm{km}^{2}$ lake surface area (i.e., for aluminium and lanthanum based products, respectively) [42]. It has also been reported that the cost of pumps alone, the traditional deep water oxygenation method for hypoxia remediation, is around $€ 0.3$ million per $\mathrm{km}^{2}$ (20,000 million Euros in $60,000 \mathrm{~km}^{2}$ hypoxia area of Baltic Sea) [22]. The estimated cost of using the MFG, considering materials, modification by chemicals and $\mathrm{O}_{2}$ nanobubbles, and other labour costs notably laboratory preparation, could be about $€$ 0.5-1.5 million per $\mathrm{km}^{2}$. Notably, future industrylevel productions for large scale application would invariably generally downsize the cost. More importantly, owing to the superior performances for simultaneous $\mathrm{NH}_{4}{ }^{+}-\mathrm{N}$ and $\mathrm{PO}_{4}{ }^{3-}-\mathrm{P}$ control and remediation of hypoxia, the proposed MFG material has the potential to become cost-effective for this engineering application.

The results from our in-situ lake experiment could represent the realistic application of the MFG materials to a certain extent. Bioturbation, such as reworking activity by tubificid worms, may, over time, mix the capping with the original surficial $(2-3 \mathrm{~cm})$ sediment [43], thereby reducing the functionality of the added materials. We have demonstrated that the oxygen-rich layer formed by adding MFG could reach up to $4 \mathrm{~cm}$ depth under the sediment [27], which may offset negative effects resulting from the dense gallery networks produced by benthos movements. Nevertheless, other factors, such as bed sediment disturbance associated with wave-movements and currents, may influence 
the capping treatment in the field-scale environment, demanding further investigations.

Restoration of the growth of submerged macrophytes plays a crucial role in sustaining the cleared state [44]. However, this is difficult to achieve in eutrophic or black, odorous, water bodies due to both constant internal nutrient release from sediment and to the persistence of anoxic conditions in the benthic zone, even after external nutrient loading has been successfully controlled [45]. With the combination of MFG capping and flocculation, the transparency of the water column may improve, the algal flocs and/or sediment resuspension can be blocked, and sediment anoxia can also be remediated. Thus, favourable conditions for re-establishment of submerged vegetation are created and thereby provide a window of opportunity for the germination and growth of submerged macrophytes. Once the submerged vegetation is successfully established, it can continue to take up the excessive nutrients from both the water column and sediment [46], effectively mitigating against further eutrophication. Nevertheless, further studies should be conducted to evaluate the long-term efficiency and the ecological responses in extensive lake systems.

\section{Conclusion}

In this study, we developed a multifunction geoengineering material (MFG), derived from natural zeolite, for control of internal nutrient loading in eutrophic water bodies, through the synergistic functions of physical capping, nutrient adsorption and $\mathrm{O}_{2}$ nanobubble delivery. The MFG significantly enhanced nutrient adsorption and $\mathrm{O}_{2}$ delivery capabilities when compared with pristine zeolite. Following the capping treatment through an in-situ experiment in a eutrophic lake, sediment hypoxia was reversed to an 
aerobic status and sediment microbial activity, particularly nitrifying bacteria, was stimulated. More importantly, each function of the MFG during the sediment remediation was quantified, whereby the $\mathrm{O}_{2}$ nanobubble delivery was determined to be the largest contributor towards the transfer of the sediment from a nutrient source to a sink. The findings could support the further investigation of the long-term effects and the corresponding multifunctional efficiency induced by the application of the MFG in largescale lake systems.

\section{Acknowledgements}

The research was supported by the National Natural Science Foundation of China (41877473, 41401551), Beijing Natural Science Foundation (8162040) and the Funds for Major Science and Technology Program for Water Pollution Control and Treatment (2018ZX07701001). We thank Dr. Mick Cooper for proof reading and suggesting improvements to the manuscript. We also thank Dr. Chunyan Ma and Dr. Xin Zhang for valuable suggestions to the data analysis.

\section{References}

[1] Conley, D.J., Paerl, H.W., Howarth, R.W., Boesch, D.F., Seitzinger, S.P., Havens, K.E., Lancelot, C. and Likens, G.E., Controlling Eutrophication: Nitrogen and Phosphorus. Science 323 (2009) 1014-1015.

[2] Yin, H., Wang, J., Zhang, R. and Tang, W., Performance of physical and chemical methods in the co-reduction of internal phosphorus and nitrogen loading from the sediment of a black odorous river. Sci. Total Environ. 663 (2019) 68-77.

[3] Paerl, H.W., Otten, T.G. and Kudela, R., Mitigating the Expansion of Harmful Algal Blooms Across the Freshwater-to-Marine Continuum. Environ. Sci. Technol. 52 (2018) $5519-5529$. 
[4] Paerl, H.W., Scott, J.T., McCarthy, M.J., Newell, S.E., Gardner, W.S., Havens, K.E., Hoffman, D.K., Wilhelm, S.W. and Wurtsbaugh, W.A., It Takes Two to Tango: When and Where Dual Nutrient (N \& P) Reductions Are Needed to Protect Lakes and Downstream Ecosystems. Environ. Sci. Technol. 50 (2016) 10805-10813.

[5] Horppila, J., Sediment nutrients, ecological status and restoration of lakes. Water Res. 160 (2019) 206-208.

[6] Qin, B., Zhou, J., Elser, J.J., Gardner, W.S., Deng, J. and Brookes, J.D., Water Depth Underpins the Relative Roles and Fates of Nitrogen and Phosphorus in Lakes. Environ. Sci. Technol. 54 (2020) 3191-3198.

[7] Liu, C., Chen, K., Wang, Z., Fan, C., Gu, X. and Huang, W., Nitrogen exchange across the sediment-water interface after dredging: The influence of contaminated riverine suspended particulate matter. Environ. Pollut. 229 (2017) 879-886.

[8] Bierlein, K.A., Rezvani, M., Socolofsky, S.A., Bryant, L.D., Wuest, A. and Little, J.C., Increased sediment oxygen flux in lakes and reservoirs: The impact of hypolimnetic oxygenation. Water Resour. Res. 53 (2017) 4876-4890.

[9] Jin, X., Bi, L., Lyu, T., Chen, J., Zhang, H. and Pan, G., Amphoteric starch-based bicomponent modified soil for mitigation of harmful algal blooms (HABs) with broad salinity tolerance: Flocculation, algal regrowth, and ecological safety. Water Res. 165 (2019) 115005.

[10] Li, X.D., Zhang, Z.Y., Xie, Q., Yang, R.J., Guan, T. and Wu, D.Y., Immobilization and Release Behavior of Phosphorus on Phoslock-Inactivated Sediment under Conditions Simulating the Photic Zone in Eutrophic Shallow Lakes. Environ. Sci. Technol. 53 (2019) 12449-12457.

[11] Huser, B.J., Futter, M., Lee, J.T. and Perniel, M., In-lake measures for phosphorus control: The most feasible and cost-effective solution for long-term management of water quality in urban lakes. Water Res. 97 (2016) 142-152.

[12] Lürling, M., Mackay, E., Reitzel, K. and Spears, B.M., Editorial - A critical perspective on geo-engineering for eutrophication management in lakes. Water Res. 97 (2016) 1-10. 
[13] Gibbs, M.M. and Hickey, C.W., Flocculants and Sediment Capping for Phosphorus Management. In: Hamilton D., Collier K., Quinn J., Howard-Williams C. (eds) Lake Restoration Handbook. Springer, Cham (2018) 207-265.

[14] Pan, M., Lyu, T., Zhang, M., Zhang, H., Bi, L., Wang, L., Chen, J., Yao, C., Ali, J., Best, S., Ray, N. and Pan, G.,2019. Synergistic Recapturing of External and Internal Phosphorus for In Situ Eutrophication Mitigation. Water-Sui 12 (2019).

[15] Silva, J.M.R., Morais, E.K.L., Silveira, J.B., Oliveira, M.H.R., Coriolano, A.C.F., Fernandes, V.J. and Araujo, A.S., Improved thermogravimetric system for processing of oil sludge using HY zeolite catalyst. J. Therm. Anal. Calorim. 136 (2019) 18611868 .

[16] Copetti, D., Finsterle, K., Marziali, L., Stefani, F., Tartari, G., Douglas, G., Reitzel, K., Spears, B.M., Winfield, I.J., Crosa, G., D'Haese, P., Yasseri, S. and Lurling, M., Eutrophication management in surface waters using lanthanum modified bentonite: A review. Water Res. 97 (2016) 162-174.

[17] Fang, L., Liu, R., Li, J., Xu, C., Huang, L.-Z. and Wang, D., Magnetite/Lanthanum hydroxide for phosphate sequestration and recovery from lake and the attenuation effects of sediment particles. Water Res. 130 (2018) 243-254.

[18] Funkey, C.P., Conley, D.J., Reuss, N.S., Humborg, C., Jilbert, T. and Slomp, C.P., Hypoxia Sustains Cyanobacteria Blooms in the Baltic Sea. Environ. Sci. Technol. 48 (2014) 2598-2602.

[19] Testa, J.M. and Kemp, W.M., Hypoxia-induced shifts in nitrogen and phosphorus cycling in Chesapeake Bay. Limnol. Oceanogr. 57 (2012) 835-850.

[20] Chen, M., Ding, S., Wu, Y., Fan, X., Jin, Z., Tsang, D.C.W., Wang, Y. and Zhang, C., Phosphorus mobilization in lake sediments: Experimental evidence of strong control by iron and negligible influences of manganese redox reactions. Environ. Pollut. 246 (2019) 472-481.

[21] Lyu, T., He, K.L., Dong, R.J. and Wu, S.B., The intensified constructed wetlands are promising for treatment of ammonia stripped effluent: Nitrogen transformations and removal pathways. Environ. Pollut. 236 (2018) 273-282. 
[22] Conley, D.J., Bonsdorff, E., Carstensen, J., Destouni, G., Gustafsson, B.G., Hansson, L.A., Rabalais, N.N., Voss, M. and Zillen, L., Tackling Hypoxia in the Baltic Sea: Is Engineering a Solution? Environ. Sci. Technol. 43 (2009) 3407-3411.

[23] Bormans, M., Marsalek, B. and Jancula, D., Controlling internal phosphorus loading in lakes by physical methods to reduce cyanobacterial blooms: a review. Aquat. Ecol. 50 (2016) 407-422.[24] Cooke GD, Welch EB, Peterson SA, Nichols SA, In: Cooke GD (ed) Restoration and management of lakes and reservoirs, 3rd edn. Taylor and Francis, Boca Raton, Florida.(2005).

[25] Singleton, V.L. and Little, J.C., Designing Hypolimnetic Aeration and Oxygenation Systems - A Review. Environ. Sci. Technol. 40 (2006) 7512-7520.

[26] Lyu, T., Wu, S., Mortimer, R.J.G. and Pan, G., Nanobubble Technology in Environmental Engineering: Revolutionization Potential and Challenges. Environ. Sci. Technol. 53 (2019) 7175-7176.

[27] Zhang, H., Lyu, T., Bi, L., Tempero, G., Hamilton, D.P. and Pan, G., Combating hypoxia/anoxia at sediment-water interfaces: A preliminary study of oxygen nanobubble modified clay materials. Sci. Total Environ. 637-638 (2018) 550-560.

[28] Yu, P., Wang, J., Chen, J., Guo, J., Yang, H. and Chen, Q., Successful control of phosphorus release from sediments using oxygen nano-bubble-modified minerals. Sci. Total Environ. 663 (2019) 654-661.

[29] Zhang, H., Chen, J., Han, M., An, W. and Yu, J., Anoxia remediation and internal loading modulation in eutrophic lakes using geoengineering method based on oxygen nanobubbles. Sci. Total Environ. 714 (2020) 136766.

[30] Shi, W., Pan, G., Chen, Q., Song, L., Zhu, L. and Ji, X., Hypoxia Remediation and Methane Emission Manipulation Using Surface Oxygen Nanobubbles. Environ. Sci. Technol. 52 (2018) 8712-8717.

[31] Liang, Z. and Ni, J.R., Improving the ammonium ion uptake onto natural zeolite by using an integrated modification process. J. Hazard. Mater. 166 (2009) 52-60.

[32] Huser, B.J., Egemose, S., Harper, H., Hupfer, M., Jensen, H., Pilgrim, K.M., Reitzel, K., Rydin, E. and Futter, M., Longevity and effectiveness of aluminum addition to 
reduce sediment phosphorus release and restore lake water quality. Water Res. 97 (2016) 122-132.

[33] Kizito, S., Luo, H.Z., Wu, S.B., Ajmal, Z., Lv, T. and Dong, R.J., Phosphate recovery from liquid fraction of anaerobic digestate using four slow pyrolyzed biochars: Dynamics of adsorption, desorption and regeneration. J. Environ. Manag. 201 (2017) 260-267.

[34] Yin, H.B., Kong, M. and Fan, C.X., Batch investigations on P immobilization from wastewaters and sediment using natural calcium rich sepiolite as a reactive material. Water Res. 47 (2013) 4247-4258.

[35] Cantú, M., López-Salinas, E. and Valente, J.S., SOx removal by calcined MgAIFe hydrotalcite-like materials: Effect of the chemical composition and the cerium incorporation method. Environ. Sci. Technol. 39 (2005) 9715-9720.

[36] Kontogiannidou, E., Karavasili, C., Kouskoura, M.G., Filippousi, M., Van Tendeloo, G., Andreadis, I.I., Eleftheriadis, G.K., Kontopoulou, I., Markopoulou, C.K., Bouropoulos, N. and Fatouros, D.G., In vitro and ex vivo assessment of microporous Faujasite zeolite (NaX-FAU) as a carrier for the oral delivery of danazol. J DRUG DELIV SCI TEC 51 (2019) 177-184.

[37] Liu, M., Ran, Y., Peng, X., Zhu, Z., Liang, J., Ai, H., Li, H. and He, Q., Sustainable modulation of anaerobic malodorous black water: The interactive effect of oxygenloaded porous material and submerged macrophyte. Water Res. 160 (2019) 70-80.

[38] Xu, H., Paerl, H.W., Qin, B., Zhu, G., Hall, N.S. and Wu, Y., Determining Critical Nutrient Thresholds Needed to Control Harmful Cyanobacterial Blooms in Eutrophic Lake Taihu, China. Environ. Sci. Technol. 49 (2015) 1051-1059.

[39] Guaya, D., Valderrama, C., Farran, A., Armijos, C. and Cortina, J.L., Simultaneous phosphate and ammonium removal from aqueous solution by a hydrated aluminum oxide modified natural zeolite. Chem. Eng. J. 271 (2015) 204-213.

[40] Wagner, M., Loy, A., Nogueira, R., Purkhold, U., Lee, N. and Daims, H., Microbial community composition and function in wastewater treatment plants. Anton Leeuw Int J G 81 (2002) 665-680. 
[41] Spears, B.M., Maberly, S.C., Pan, G., Mackay, E., Bruere, A., Corker, N., Douglas, G., Egemose, S., Hamilton, D., Hatton-Ellis, T., Huser, B., Li, W., Meis, S., Moss, B., Lurling, M., Phillips, G., Yasseri, S. and Reitzel, K., Geo-Engineering in Lakes: A Crisis of Confidence? Environ. Sci. Technol. 48 (2014) 9977-9979.

[42] Spears, B.M., Dudley, B., Reitzel, K. and Rydin, E., Geo-Engineering in Lakes-A Call for Consensus. Environ. Sci. Technol. 47 (2013) 3953-3954.

[43] Yin, H.B., Zhu, J.C. and Tang, W.Y., Management of nitrogen and phosphorus internal loading from polluted river sediment using Phoslock $(\mathrm{R})$ and modified zeolite with intensive tubificid oligochaetes bioturbation. Chem. Eng. J. 353 (2018) 46-55.

[44] Spears, B.M., Mackay, E.B., Yasseri, S., Gunn, L.D.M., Waters, K.E., Andrews, C., Cole, S., De Ville, M., Kelly, A., Meis, S., Moore, A.L., Nurnberg, G.K., van Oosterhout, F., Pitt, J.A., Madgwick, G., Woods, H.J. and Lurling, M., A meta-analysis of water quality and aquatic macrophyte responses in 18 lakes treated with lanthanum modified bentonite (Phoslock (R)). Water Res. 97 (2016) 111-121.

[45] Lyu, T., Song, L., Chen, Q. and Pan, G., Lake and River Restoration: Method, Evaluation and Management. Water-Sui 12 (2020) 977.

[46] Zhang, H., Shang, Y., lyu, T., Chen, J. and Pan, G., Switching Harmful Algal Blooms to Submerged Macrophytes in Shallow Waters Using Geo-engineering Methods: Evidence from a 15N Tracing Study. Environ. Sci. Technol. 52 (2018) 11778-11785. 